\title{
Rancang Bangun Aplikasi Game Edukasi Tebak Gambar Dan Fuzzle Untuk Anak Usia Dini
}

\author{
Bayu Ramdhan Huzena ${ }^{2}$, Fatmawati ${ }^{1,{ }^{*}}$, Popon Handayani ${ }^{1}$ \\ 1 Program Studi Sistem Informasi; STMIK Nusa Mandiri; JIn. Damai No. 8 Warung Jati \\ Barat(Margasatwa) Jakarta Selatan; Telp (021) 78839513; e-mail: \\ fatmawati.fmw@nusamandiri.ac.id; popon.pph@ nusamandiri.ac.id \\ 2 Program Studi Teknik Informatika; STMIK Nusa Mandiri; JIn. Damai No. 8 Warung Jati \\ Barat(Margasatwa) Jakarta Selatan; Telp (021) 78839513; e-mail: byuramdhan@yahoo.co.id \\ *Korespondensi: e-mail: fatmawati.fmw@nusamandiri.ac.id
}

Diterima: 12 Mei 2020 ; Review: 13 Mei 2020 Disetujui: 27 Mei 2020; Diterbitkan: 17 Juni 2020

\begin{abstract}
One form of entertainment that is familiar and indeed much in demand in our lives is the game. Games are applications that are familiar to the community and also early childhood from all walks of life. But the development of the game itself is currently still dominated by productions from abroad. In this study the authors chose early childhood as a sample of game users because remembering children prefer playing games rather than learning theoretically. From the existing problems, in this study the authors built an educational game application so that children can learn while playing. The purpose of this study is to facilitate children in the learning process in the form of games and the existence of educational guessing game pictures of animals and puzzles is expected to improve the ability of children in the learning process. The method used in this study is the method of data collection consisting of observations, interviews, and literature studies, for supporting tools used, namely UML (Unified Modeling Language) while the algorithm used by Fisher-Yates which functions to change the order of questions in educational game applications. With this educational guessing game application, guess the picture of animals and puzzle can make it easier for children in the process of learning to recognize the animals that exist on this earth.
\end{abstract}

Keywords: Games, Guess Pictures, Puzzles, UML (Unified Modeling Language), Fisher Yates

\begin{abstract}
Abstrak
Salah satu bentuk hiburan yang tidak asing lagi dan memang banyak diminati dalam kehidupan kita adalah game. Game merupakan aplikasi yang tidak asing lagi bagi masyarakat dan juga anak-anak usia dini dari segala lapisan. Namun perkembangan game itu sendiri saat ini masih di dominasi oleh produksi-produksi dari luar negeri. Pada penelitian ini penulis memilih anakanak usia dini sebagai sampel pengguna game karena mengingat anak-anak lebih suka bermain game dibandingkan belajar secara teoritis. Dari permasalahan yang ada maka pada penelitian ini penulis membangun sebuah aplikasi game edukasi agar anak-anak bisa belajar sambil bermain. Tujuan dari penelitian ini yaitu untuk mempermudah anak-anak dalam proses pembelajaran dalam bentuk game dan dengan adanya game edukasi tebak gambar hewan dan puzzle ini diharapkan dapat meningkatkan kemampuan anak-anak dalam proses belajar. Metode yang digunakan pada penelitian ini yaitu metode pengumpulan data yang terdiri dari observasi, wawancara dan studi pustaka, untuk tools pendukung yang digunakan yaitu UML(Unified Modeling Language) sedangkan Algoritma yang digunakan Fisher Yates yang berfungsi untuk merubah urutan soal pada aplikasi game edukasi. Dengan adanya aplikasi game edukasi tebak gambar hewan dan fuzzle ini dapat mempermudah anak-anak dalam proses belajar mengenal hewan-hewan yang ada di bumi ini.
\end{abstract}

Kata kunci: Game, Tebak Gambar, Puzzle, UML (Unified Modeling Language), Fisher Yates 


\section{Bayu Ramdhan Huzena, Fatmawati, Popon Handayani}

\section{Pendahuluan}

Saat ini perkembangan teknologi di Indonesia semakin pesat, anak-anak usia dini telah banyak menggunakan smartphone, dari perkembangan teknologi yang telah diikuti oleh anak anak usia dini, pengguna game ini diharuskan untuk mencocokan gambar dan huruf sesuai dengan yang ada dilayar. Permainan game yang di buat ini mempunyai unsur edukatif yang dapat merangsang perkembangan otak. Penerapan game untuk media pendidikan atau yang disebut education game bermula dari perkembangan video game yang sangat pesat dan menjadikannya sebagai media alternatif untuk kegiatan pembelajaran. Menurut (Trisna, 2015) menyimpulkan bahwa media disebut juga alat-alat audio visual, artinya alat yang dapat dilihat dan didengar yang dipakai dalam proses pembelajaran dengan maksud untuk membuat cara berkomunikasi lebih efektif dan efisien. Dengan penggunaan alat-alat ini guru dan siswa dapat berkomunikasi lebih mantap dan hidup serta interaksinya bersifat banyak arah.Menurut (Giyartono \& Kresnha, 2015) Android adalah operating system atau OS berbasis linux yang diperuntukan khusus untuk mobile device seperti smartphone atau PC table, persis seperti yang digunakan oleh Nokia dan Blackberry OS, jelasnya seperti Microsoft windows yang sangat dikenal baik oleh para pengguna komputer dan laptop, jika kita analogikan, android adalah windows nya sedangkan smartphone atau handphone atau tablet adalah unit komputernya.

Pemanfaatan Smartphone sebagai media hiburan serta memudahkan para pengguna untuk media pembelajaran dan mencari informasi dengan semakin canggih dan majunya teknologi banyak pengembang dapat menciptakan inovasi terhadap aplikasi yang dapat berjalan di smartphone di android.

\section{Metode Penelitian}

Metode penelitian yang penulis gunakan dalam kegiatan penelitian ini yaitu dengan dua cara: Pertama, Teknik Pengumpulan Data terdiri dari: 1) Observasi, Pada tahapan ini penulis melakukan pengamatan langsung ke sekolah PAUD. 2) Wawancara, Pada tahapan ke dua ini penulis melakukan tanya jawab langsung kepada Bapak Maulana Akbar sebagai pengajar anak-anak pada usia dini untuk memperoleh informasi yang dapat dijadikan sebagai bahan penyusunan artikel. 3) Studi Kepustakaan, Selain melakukan kegiatan diatas penulis juga melakukan studi kepustakaan melalui literatur-literatur atau referensi dan juga melalui internet. Kedua, Model Pengembangan Sistem, Metode penelitian yang diterapkan pada penelitian ini adalah dengan pengembangan metode waterfall. Menurut (Sasmito, 2017) Metode waterfall merupakan model pengembangan sistem informasi yang sistematik dan sekuensial. Metode Waterfall memiliki tahapan-tahapan sebagai berikut: 


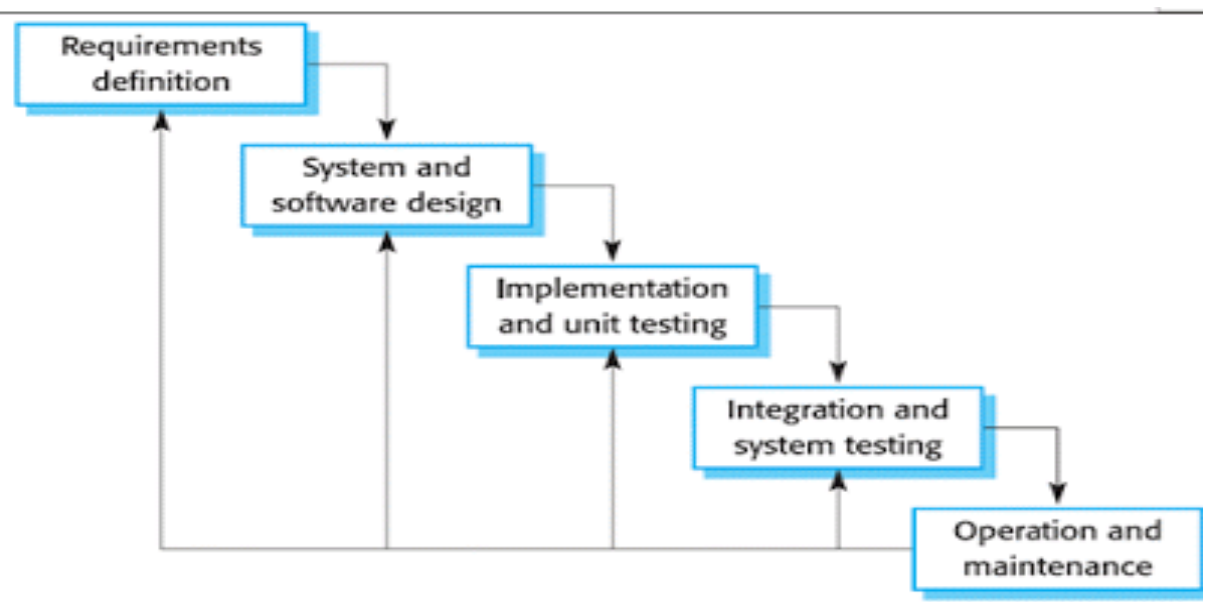

Sumber: Hasil Penelitian (2019)

Gambar 1. Model Waterfall

Tahapan Model waterfall dapat dijelaskan sebagai berikut:

1. Requirements analysis and definition

Layanan sistem, kendala, dan tujuan ditetapkan oleh hasil konsultasi dengan pengguna yang kemudian didefinisikan secara rinci dan berfungsi sebagai spesifikasi sistem.

2. System and software design

Tahapan perancangan sistem mengalokasikan kebutuhan-kebutuhan sistem baik perangkat keras maupun perangkat lunak dengan membentuk arsitektur sistem secara keseluruhan. Perancangan perangkat lunak melibatkan identifikasi dan penggambaran abstraksi sistem dasar perangkat lunak dan hubungannya.

3. Implementation and unit testing

Pada tahap ini, perancangan perangkat lunak direalisasikan sebagai serangkaian program atau unit program. Pengujian melibatkan verifikasi bahwa setiap unit memenuhi spesifikasinya.

4. Integration and system testing

Unit-unit individu program atau program digabung dan diuji sebagai sebuah sistem lengkap untuk memastikan apakah sesuai dengan kebutuhan perangkat lunak atau tidak. Setelah pengujian, perangkat lunak dapat dikirimkan ke customer.

5. Operation and maintenance

Tahapan ini merupakan tahapan yang paling panjang. Sistem dipasang dan digunakan secara nyata. Maintenance melibatkan pembetulan kesalahan yang tidak ditemukan pada tahapan-tahapan sebelumnya, meningkatkan implementasi dari unit sistem, dan meningkatkan layanan sistem sebagai kebutuhan baru.

\section{Hasil dan Pembahasan}

\subsection{Analisa Kebutuhan Aplikasi}




\section{Bayu Ramdhan Huzena, Fatmawati, Popon Handayani}

Pada bagian ini dibagi menjadi dua bagian yaitu analisa kebutuhan fungsional dan analisa kebutuhan non-fungsional.

1. Analisa Kebutuhan Fungsional

Pada Analisa Kebutuhan Fungsional berisi proses-proses apa saja yang dapat dilakukan oleh sistem aplikasi. Pada aplikasi yang dibuat memiliki fitur-fitur sebagai berikut :

a. Aplikasi dapat menampilkan menu utama.

b. Aplikasi dapat menampilkan menu game puzzle dan setelah memilih game puzzle akan menampilkan play gambar puzzle.

c. Aplikasi dapat menampilkan menu quis tebak gambar hewan dan setelah memilih menu tebak gambar hewan akan muncul play game quis tebak gambar.

d. Aplikasi menampilkan menu yang berisi profil penulis.

2. Analisa Kebutuhan Non-Fungsional

Pada analisa kebutuhan non-fungsional ini dilakukan untuk mengetahui sepesifikasi kebutuhan sistem yang dilakukan dalam perancangan aplikasi game tebak gambar dan fuzzle. Analisa kebutuhan non-fungsional ini dilakukan untuk mengetahui sepesifikasi kebutuhan sistem yang dilakukan dalam perancangan aplikasi game tebak gambar dan fuzzle.

\subsection{Metode Algoritma Fisher Yates Shuffle}

Menurut (Edora, 2018) berdasarkan penemunya, (Ronald Fisher dan Frank Yates) digunakan untuk mengubah urutan masukan yang diberikan secara acak. Permutasi yang dihasilkan oleh algoritma ini muncul dengan probabilitas yang sama. Metode dasar yang diberikan untuk menghasilkan permutasi acak dari angka 1 - $\mathrm{N}$ berjalan sebagai berikut.

\begin{tabular}{lcccc} 
& \multicolumn{4}{c}{ Tabel 1. Algoritma Fisher Yates } \\
& Range & Roll & Scratch & Result \\
& & & 12345678 \\
& $1-8$ & 4 & 1238567 & 4 \\
\hline $1-7$ & 3 & 127856 & 34 \\
\hline $1-6$ & 1 & 62785 & 134 \\
\hline $1-5$ & 2 & 6578 & 2134 \\
\hline $1-4$ & 4 & 657 & 82134 \\
\hline $1-3$ & 1 & 75 & 682134 \\
\hline $1-2$ & 1 & 5 & 7682134 \\
\hline & & & & 57682134 \\
\hline
\end{tabular}

Metode algoritma yang digunakan adalah Algoritma fisher yates shuffle dimana dalam algoritma tersebut dapat mengacak gambar-gambar yang ada menjadi tidak beurutan. Dalam 
menu utama terdapat menu yang diacak dengan menggunakan logika algoritma fisher yates shuffle.

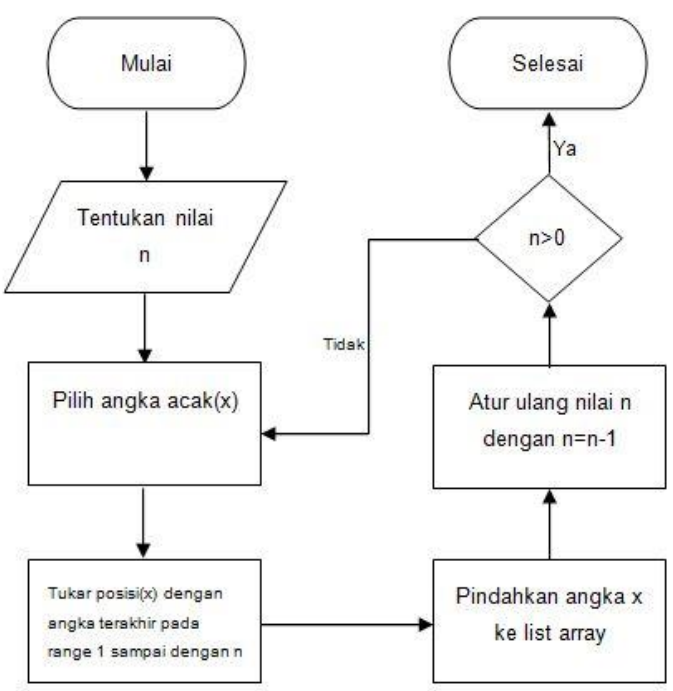

Sumber: Hasil Penelitian (2019)

Gambar 2. Algoritma fisher yates shuffle

\subsection{UML(United Modelling Language)}

Menurut (Simaremare et al., 2013) UML merupakan bahasa visual dalam pemodelan yang memungkinkan pengembang sistem membuat sebuah blueprint yang dapat menggambarkan visi mereka tentang sebuah sistem dalam format yang standar, mudah dimengerti, dan menyediakan mekanisme untuk mudah dikomunikasikan dengan pihak lain Berikut ini adalah beberapa jenis UML diagram yang biasa digunakan:

1. Use Case Diagram

Use Case merupakan pemodelan untuk melakukan sistem informasi yang akan Dibuat.

a. Use Case Menu Utama

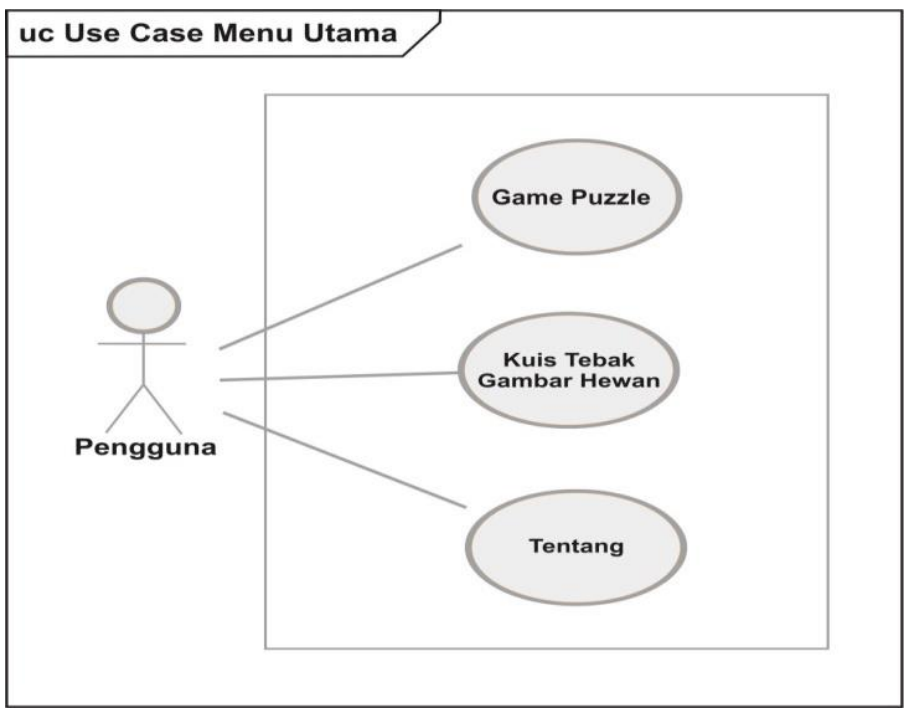

Sumber: Hasil Penelitian (2019)

Gambar 3. Diagram Use Case Menu Utama 
b. Use Case Menu Game Puzzle

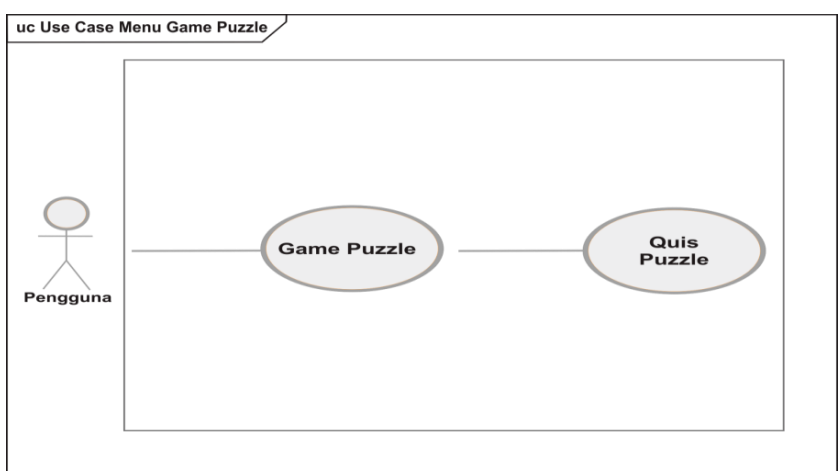

Sumber: Hasil Penelitian (2019)

Gambar 4. Diagram UseCase Menu Game Puzzle

c. Use Case Kuis Tebak Gambar Hewan

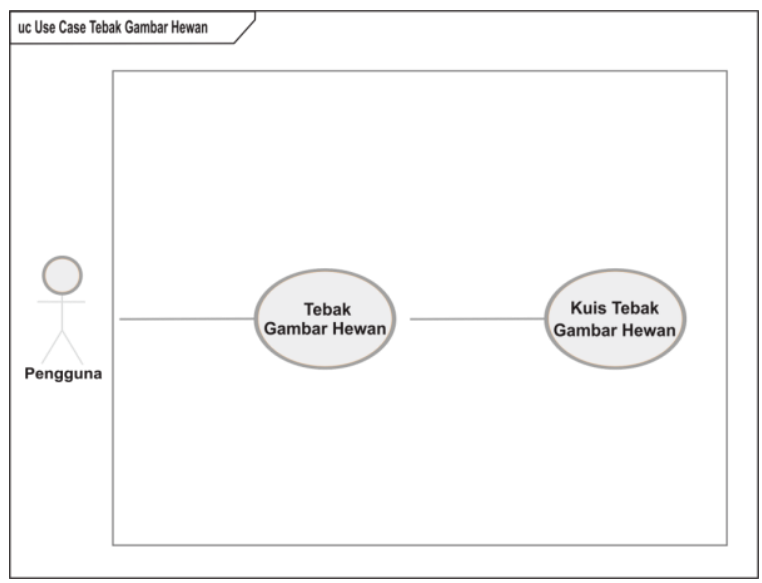

Sumber: Hasil Penelitian (2019)

Gambar 5. Diagram UseCase Kuis Tebak Gambar Hewan

2. Activity Diagram

Activity Diagram menggambarkan workflow (aliran kerja) atau aktivitas dari sebuah sistem atau proses bisnis atau menu yang ada pada perangkat lunak.

a. Activity Diagram Game Puzzle

Pada activity Diagram ini pengguna memilih menu game puzzle pada menu utama.

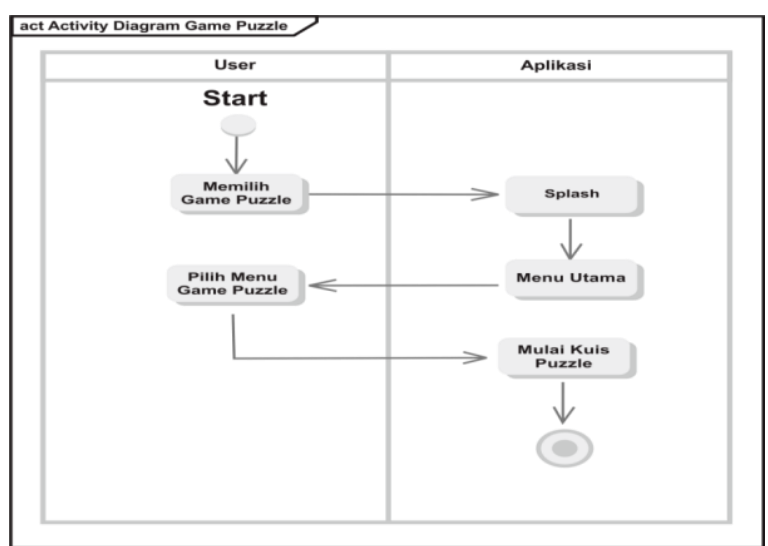

Sumber: Hasil Penelitian (2019)

Gambar 6. Diagram Activity Menu Game Puzzle 
b. Activity Diagram Tebak Gambar Hewan

Pada activity Diagram ini pengguna memilih menu tebak gambar hewan pada menu utama.

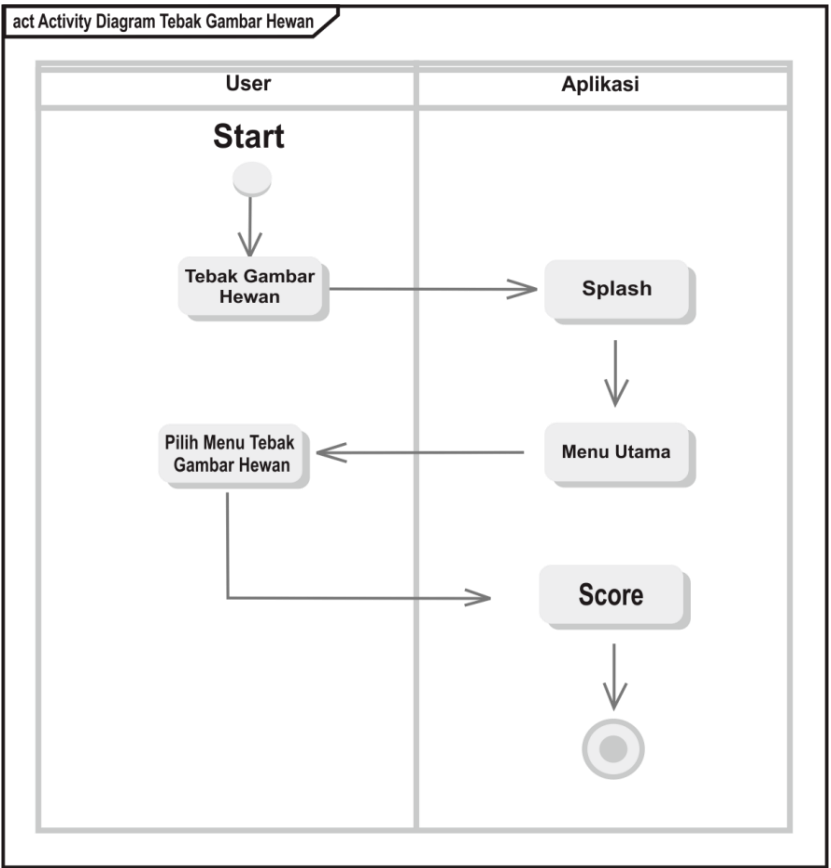

Sumber: Hasil Penelitian (2019)

Gambar 7. Diagram Activity Tebak Gambar Hewan

3. Deployment Diagram

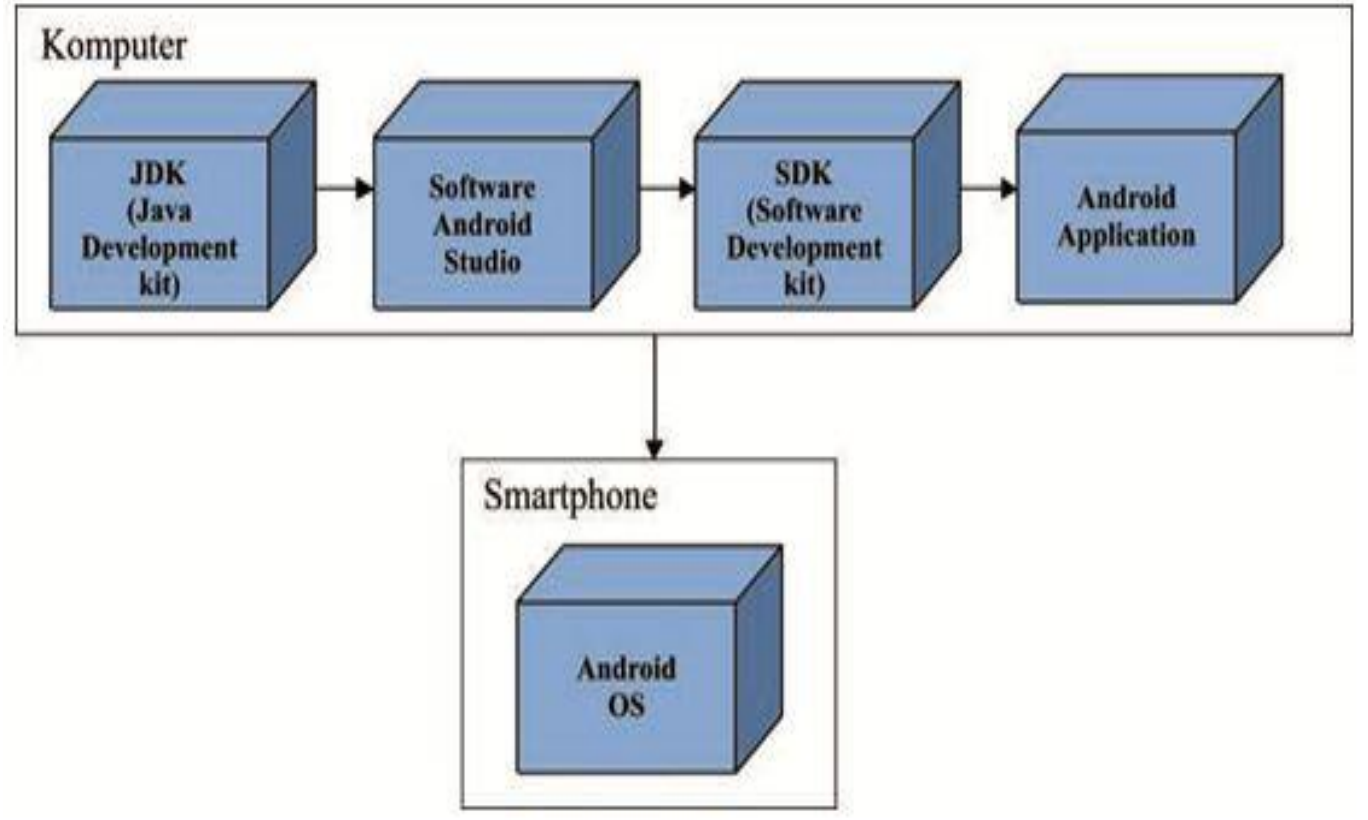

Sumber: Hasil Penelitian (2019)

Gambar 8. Deployment Diagram 
4. Squence Diagram

a. Squence Diagram Menu Utama

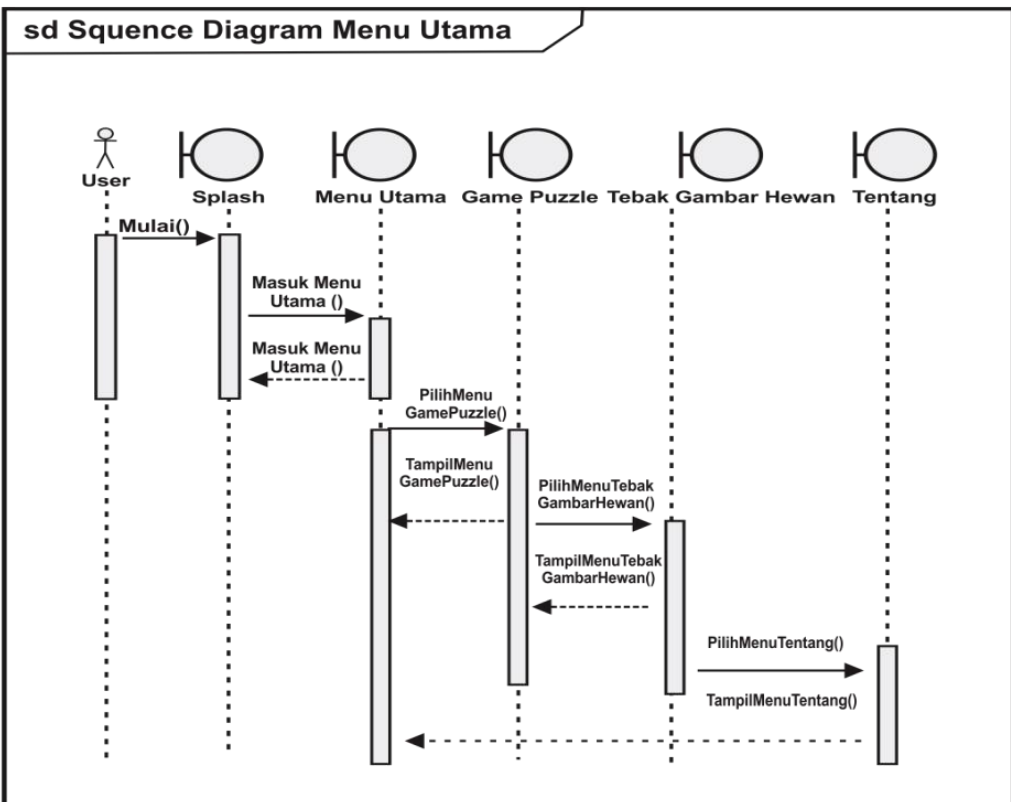

Sumber: Hasil Penelitian (2019)

\section{Gambar 9. Squence Menu Utama}

b. Squence Diagram Game Puzzle

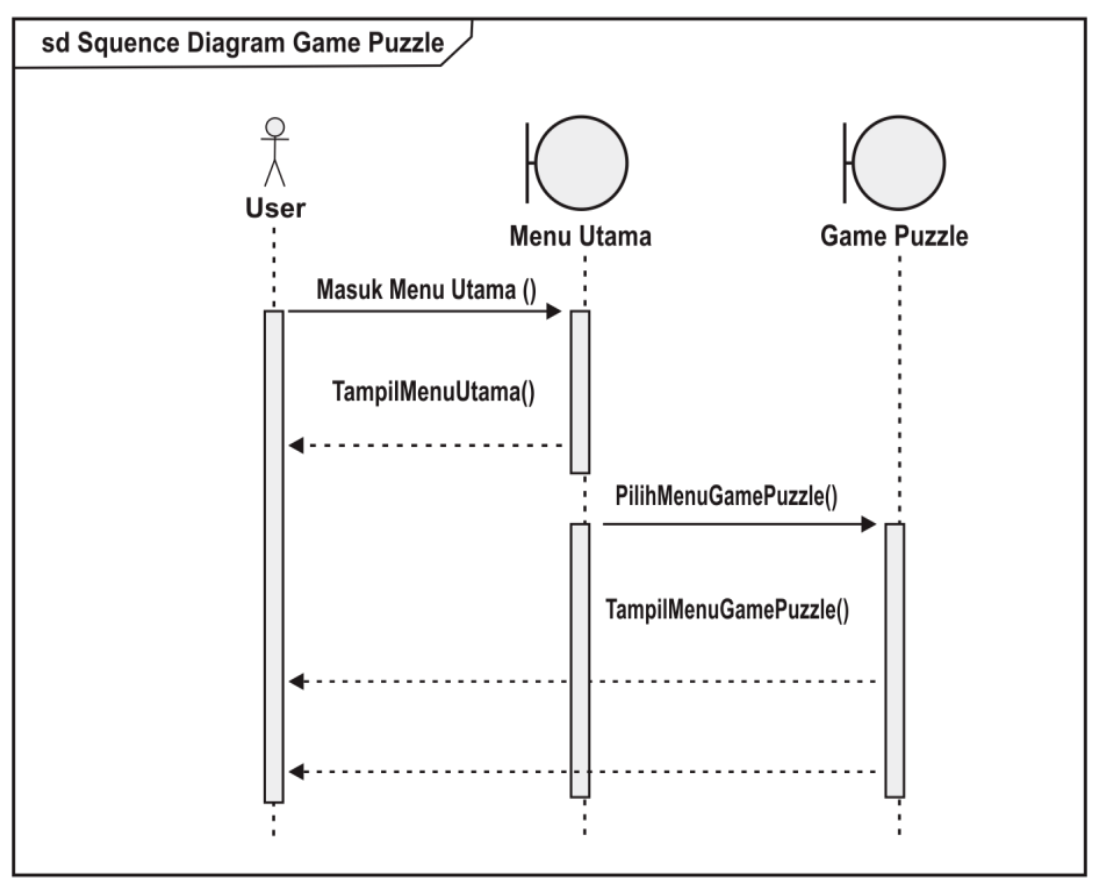

6. Sumber: Hasil Penelitian (2019)

Gambar 10. Squence Menu Game Puzzle 
a. Squence Diagram Kuis Tebak Gambar Hewan

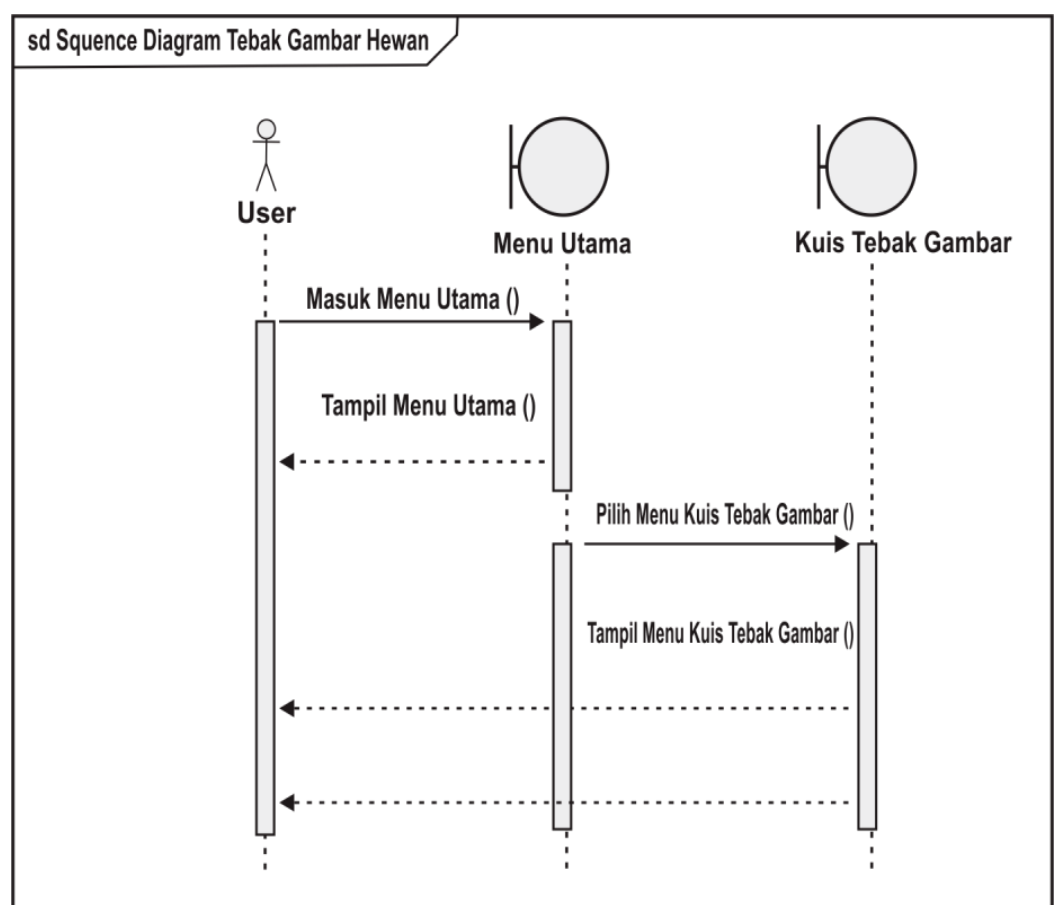

Sumber: Hasil Penelitian (2019)

Gambar 11. Squence Menu Kuis Tebak Gambar Hewan

\subsection{Black Box Testing}

Menurut Khan dalam (Mustaqbal et al., 2015) Black-Box Testing merupakan pengujian yang berfokus pada spesifikasi fungsional dari perangkat lunak, tester dapat mendefinisikan kumpulan kondisi input dan melakukan pengetesan pada spesifikasi fungsional program. Metode yang diapakai untuk pengujian adalah Black Box, berikut hasil pengujiannya:

Tabel 2. Black Box Testing

\begin{tabular}{ccccc}
\hline No & Skenario & Test Case & $\begin{array}{c}\text { Hasil yang } \\
\text { diharapkan }\end{array}$ & Keterangan \\
\hline 1 & $\begin{array}{c}\text { Tampil Menu } \\
\text { Utama }\end{array}$ & $\begin{array}{c}\text { Menampilkan } \\
\text { halaman menu } \\
\text { utama }\end{array}$ & $\begin{array}{c}\text { Tampil halaman } \\
\text { Menu Utama }\end{array}$ & Berhasil \\
\hline 2 & $\begin{array}{c}\text { Memilih game } \\
\text { Fuzzle }\end{array}$ & $\begin{array}{c}\text { Menampilkan menu } \\
\text { game Fuzzle }\end{array}$ & $\begin{array}{c}\text { Tampil menu } \\
\text { quis game fuzzle }\end{array}$ & Berhasil \\
\hline 3 & $\begin{array}{c}\text { Memilih Tebak } \\
\text { Gambar Hewan }\end{array}$ & $\begin{array}{c}\text { Menampilkan Tebak } \\
\text { Gambar Hewan }\end{array}$ & $\begin{array}{c}\text { Tampil menu } \\
\text { quis tebak } \\
\text { gambar }\end{array}$ & Berhasil \\
\hline 4 & Memilih & Menampilkan & $\begin{array}{c}\text { Tampil halaman } \\
\text { tentang }\end{array}$ & Berhasil \\
\hline
\end{tabular}

Sumber: Hasil Penelitian (2019)

\subsection{Implementasi}

Implementasi merupakan tahap dimana sistem di operasikan pada tahap yang sebenarnya, sehingga akan diketahui apakah sistem yang telah dibuat benar-benar sesuai atau tidak. 
1. Tampilan Splash Screen

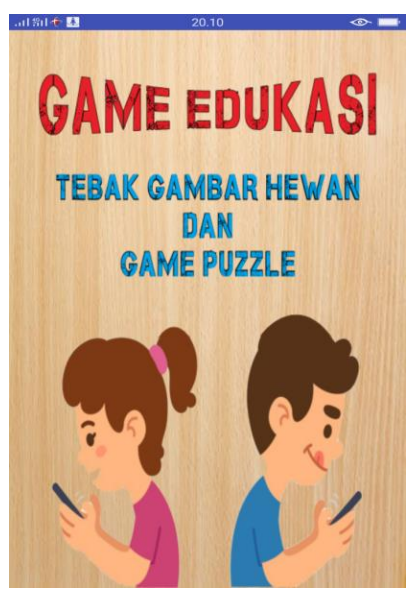

Sumber: Hasil Penelitian (2019)

Gambar 12. Splash Screen

2. Tampilan Menu Utama

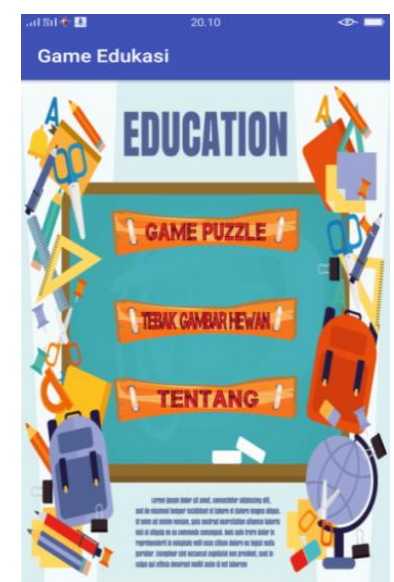

Sumber: Hasil Penelitian (2019)

Gambar 13. Menu Utama

3. Menu Game Puzzle

Sumber: Hasil Penelitian (2019)

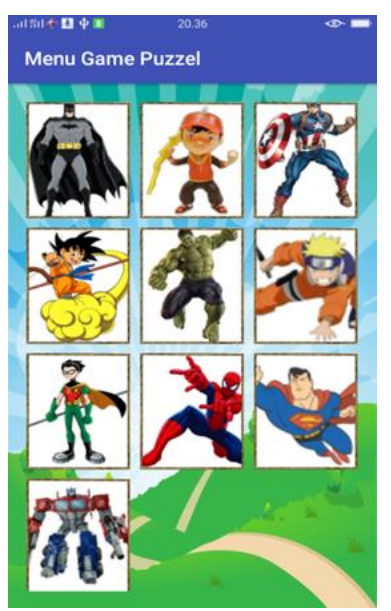

Gambar 14. Menu Game Puzzle 
4. Menu Quis Tebak Gambar

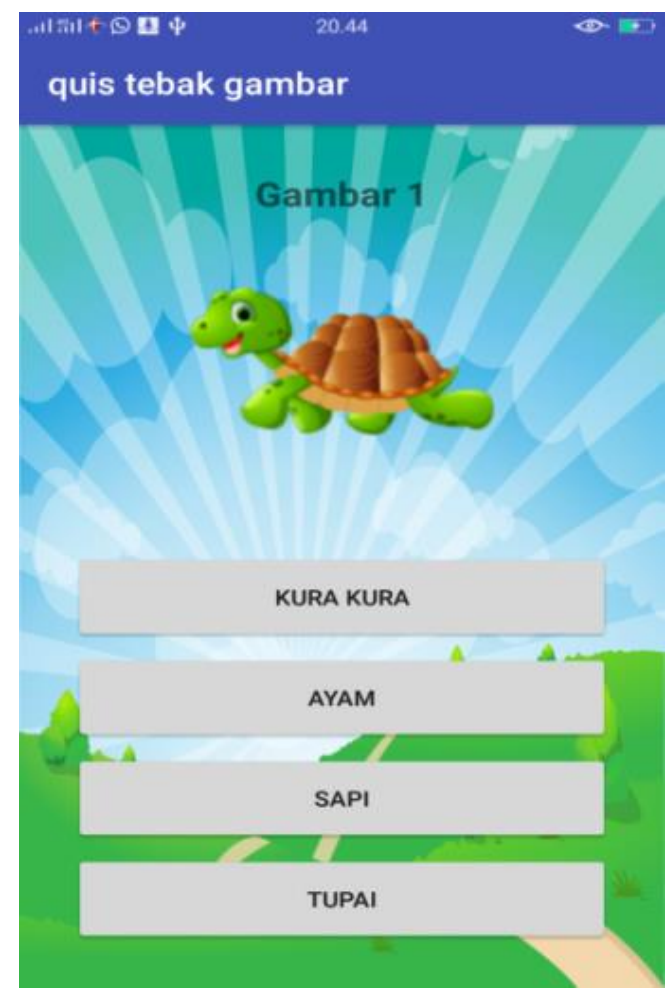

Sumber: Hasil Penelitian (2019)

Gambar 15. Menu Quis Tebak Gambar

\section{Kesimpulan}

Rancang bangun Aplikasi Game Edukasi Tebak Gambar dan Game Puzzle Untuk Anak Usia Dini dengan menggunakan algoritma Fisher Yates ini mampu mengatasi permasalahan yang ada yaitu memudahkan anak usia dini untuk mengenal nama-nama binatang dan dengan adanya aplikasi tebak gambar lebih tanggap mengenal nama-nama hewan.

\section{Daftar Pustaka}

Edora, S. F. (2018). Rancang Bangun Game Edukasi Puzlle Sebagai Media Pembelajaran Berbasis Android Menggunakan Algoritma Fisher-Yates Shuffle (Studi Kasus Di Sdn 2 Ngumbul Todanan - Blora ). 13(2), 32-38.

Giyartono, A., \& Kresnha, E. (2015). Aplikasi Android Pengendali Lampu Rumah Berbasis Mikrokontroler Atmega328. Seminar Nasional Sains Dan Teknologi, November, 1-9.

Mustaqbal, M. S., Firdaus, R. F., \& Rahmadi, H. (2015). Pengujian Aplikasi Menggunakan Black Box Testing Boundary Value Analysis (Studi Kasus: Aplikasi Prediksi Kelulusan SNMPTN). I(3), 31-36.

Sasmito, G. W. (2017). Penerapan Metode Waterfall Pada Desain Sistem Informasi Geografis Industri Kabupaten Tegal. Jurnal Informatika:Jurnal Pengembangan IT (JPIT), 2(1), 6-12.

Simaremare, Y. P. W., Pribadi, A., Radityo, S., \& Wibowo, P. (2013). Perancangan dan Pembuatan Aplikasi Manajemen Publikasi IImiah Berbasis Online pada Jurnal SISFO. Jurnal Teknik ITS, 2(3), 470-475. 
Bayu Ramdhan Huzena, Fatmawati, Popon Handayani

Trisna, S. (2015). Pembuatan Game Pembelajaran Pengenalan Huruf Hijaiyah Di Taman Kanak-Kanak (TK) Az-Zalfa Sidoharjo Pacitan. Journal Speed-Sentra Penelitian Engineering Dan Edukasi, 6(1), 7. 